\title{
イネ科花粉症に対するアゼラスチンの効果
}

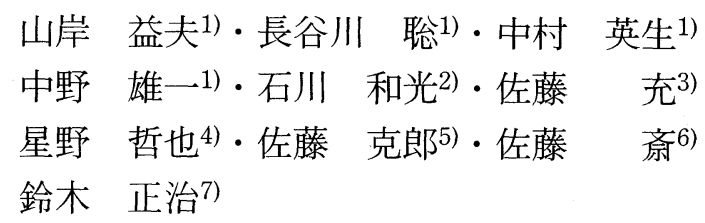

\section{Azelastine in the Treatment and Prevention of Seasonal Grass Pollinosis}

\author{
Masuo Yamagishi, Satoshi Hasegawa, Hideo Nakamura \\ and Yuichi Nakano (Niigata University), \\ Kazumitsu Ishikawa (Japan Dental University), \\ Mitsuru Sato (Niigata Prefecture Central Hospital), \\ Tetsuya Hoshino (Ojiya General Hospital), \\ Katsuro Sato (Murakami Hospital), \\ Hitoshi Sato (Sado General Hospital), \\ Shoji Suzuki (Niigata Prefectural Tokamachi Hospital)
}

Azelastine was administered to 36 patients with grass pollinosis (timothy and orchard grass) for prevention and treatment.

In the patients who started before the beginning of the pollen season, azelastine was very effective, and the rate of prevention of nasal and ocular symptoms of allergy was over $90 \%$. When azelastine treatment was initiated after the onset of allergic symptoms the rate of improvement was not so high.

Side effects appeared in only 3 patients (8.3\%), mainly somnolence.

These results indicate that azelastine therapy before the beginning of the pollen season is a useful method to prevent the symptoms of grass pollinosis.

Key words: azelastine, grass pollinosis, preventive effect, treatment effect, side effect

はじめに

オオアワガエリ拉よ゙カモガヤ花粉症は初夏 にみられるイネ科花粉症の中心を占めるもので, 日本海側の新潟県でも最近患者数が増加傾向に
ある．本県では春の花粉症の代表であるスギ花 粉症揖よび秋の花粉症であるヨモギ花粉症に迫 る勢いとなって扣り，その対策が問題となって いる．スギ花粉症に対してはすでに種々の薬剤
1) 新潟大学医学部耳鼻咽喉科学教室

3）新潟県立中央病院耳鼻咽喉科

5）厚生連村上病院耳鼻咽喉科

7）新潟県立十日町病院耳鼻咽喉科（現：立川総合病院）
2）日本歯科大学新潟歯学部付属病院耳鼻咽喉科

4）小千谷総合病院耳鼻咽喉科

6）厚生連佐渡総合病院耳鼻咽喉科 
による多くの報告がなされて拈り1) 6)，いずれ も予防投与の有用性を示している.これらの結 果からみてスギ花粉症ばかりでなく他の花粉症 に対しても当然同様の効果が期待できるはずで ある。そこで今回はアゼラスチンをオオアワガ エリ扣よびカモガヤ花粉症患者に花粉飛散前か ら投与し，その予防効果を検討すると同時に， 症状発生後に投与した群の治療効果もあわせて 検討したので報告する。

\section{方法}

1. 対 象

1990年以前にオオアワガエリあるいはカモガ ヤ花粉症と診断された患者に対してあらかじめ 受診依頼表を送付し，この依頼に基づいて治験 参加施設に来院した患者を対象とした。患者選 択基準は予防投与群では受診時の症状が軽症ま たは無症状であること，また発症後投与群では 原則として重症または中等症であることとした． さらに年齢は15歳以上の患者であることとした． また例年イネ科花粉飛散期に症状があり，才才 アワガエリあるいはカモガヤ(または両者)の皮 内反応扣よび RAST 陽性のものをイネ科花粉 症と診断した。 その他の除外基準は一般の抗了 レルギー剤の治験と同様である。

\section{2. 投与方法}

予防投与を希望した患者は，受診日よりアゼ ラスチン錠(アゼプチン®：アゼラスチンとし
て $1 \mathrm{mg}$ 含有)を 1 日 2 回投与した。その他の 患者は症状が発症してからアゼラスチン錠を 1 日 2 回投与した。

\section{3 。治験期間}

予防投与は例年新潟県でイネ科花粉が飛散し 始める時期のほ核 2 週間前である 4 月中旬から 開始し， 5 月下旬までとした．発症後投与は患 者が受診した日より開始し，4 週間継続した。

\section{4. 観察項目}

1）鼻症状と眼症状の程度：治験期間中の自 覚的鼻症状, 眼症状の程度は前もって患者に渡 した鼻アレルギー日記の記載から奥田の基準7 に従って分類した.

2 ）副作用：副作用は問診，視診などにより 担当医が認めた強さ，性質，処置，転帰，アゼ ラスチンとの因果関係を記載した.

3 ）患者印象：患者印象は治験終了時に問診 にて調査した。

4 ）一般臨床検查：血液検查, 血液生化学検 査，尿検査などを投与前後で計 2 回測定した.

5. イネ科花粉飛散数測定

試験期間中のイネ科花粉量は Durham 型花 粉収集器にて治験参加 7 施設 (図 1 ) にて毎日測 定，記録した。

6. 効果判定

1) 症状別効果：鼻アレルギー日記に基づい ての鼻症状および眼症状の程度の変化を参考に

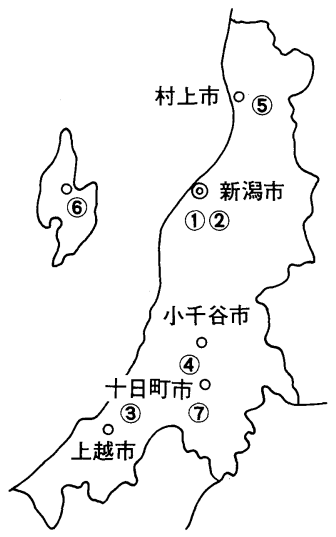

(1) 新潟大学

(2) 日本歯科大学新潟歯学部付属病院

(3) 新潟県立中央病院

(4) 小千谷総合病院

(5) 厚生連村上総合病院

(6) 厚生連佐渡総合病院

(7) 新潟県立十日町病院

図 1 治験参加施設 
して効果判定会 (新潟大学医学部耳鼻咽喉科)で 判定した. 予防投与群では表 1 の判定基準に従 い, 「著明な予防効果あり」,「中等度の予防効 果㐫り」,「軽度の予防効果あり」, 「予防効果な し」の 4 段階で判定した. 効果判定の時期は患 者の症状が最も著明となった 5 月中旬とした. 発症後投与群では表 2 の判定基準に従い,「著

表 1 症状別予防効果判定基準

\begin{tabular}{|l|l|}
\hline \multicolumn{1}{|c|}{ 評 価 } & \multicolumn{1}{c|}{ 重症度の変化 } \\
\hline 著明な予防効果あり & $-\rightarrow-,+\rightarrow+,+\rightarrow-$ \\
\hline 中等度の予防効果あり & $-\rightarrow+,+\rightarrow \mathrm{H}$ \\
\hline 軽度の予防効果あり & $-\rightarrow \mathrm{H},+\rightarrow \mathrm{m}$ \\
\hline 効果なし & $-\rightarrow \mathrm{m}$ \\
\hline
\end{tabular}

表 2 症状別治療効果判定基準

\begin{tabular}{|c|c|}
\hline 評 価 & 重症度の変化 \\
\hline 著明改善 & $H \rightarrow-, \quad H \rightarrow-, \quad+\rightarrow-$ \\
\hline 中等度改善 & $\mathrm{W} \rightarrow+$ \\
\hline 軽度改善 & $\mathrm{H} \rightarrow \mathrm{H}, \mathrm{H} \rightarrow+$ \\
\hline 不 変 & $\mathrm{H} \rightarrow \mathrm{H}, \mathrm{H} \rightarrow \mathrm{H}, \quad+\rightarrow+$ \\
\hline 悪 化 & $\begin{array}{l}\mathrm{H} \rightarrow \mathrm{H},+\underset{\mathrm{H}}{\mathrm{H}} \cdot \mathrm{H}, \\
\rightarrow+\mathrm{H} \cdot \mathrm{H}\end{array}$ \\
\hline
\end{tabular}

明改善」,「中等度改善」,「軽度改善」,「不変」, 「悪化」の 5 段階で判定した.

2) 全般的予防効果括よび治療効果: 症状別 の効果を参考にして効果判定会で予防投与群で は「著明な予防効果あり」, 「中程度の予防効果 あり」, 「軽度の予防効果あり」, 「予防効果なし」 の 4 段階で, また発症後投与群では「著明改善」, 「中等度改善」,「やや改善」,「不变」,「悪化」 の 5 段階で判定した。

3) 有用度: 予防投与群执よび発症後投与群 とも自・他覚的症状, 副作用などを総合して担 当医が「きわめて有用」,「有用」,「やや有用」, 「どちらともい亲ない」,「有用でない」の5段 階で判定した.

\section{成 績}

1. イネ科花粉飛散状況

治験期間中の 1990 年 5 月 1 日より 6 月 7 日ま での新潟県内治験参加施設での花粉飛散状況を 図 2 に示す. 花粉飛散が増加し始めたのは各地 域によって多少差はあるが 5 月 3 日頃からで， その後数日括きにピークをつくり，5月20日頃 までかなり多くの飛散が続いた，その後は減少 するが 6 月に入っても小さなピークが時々みら れた。

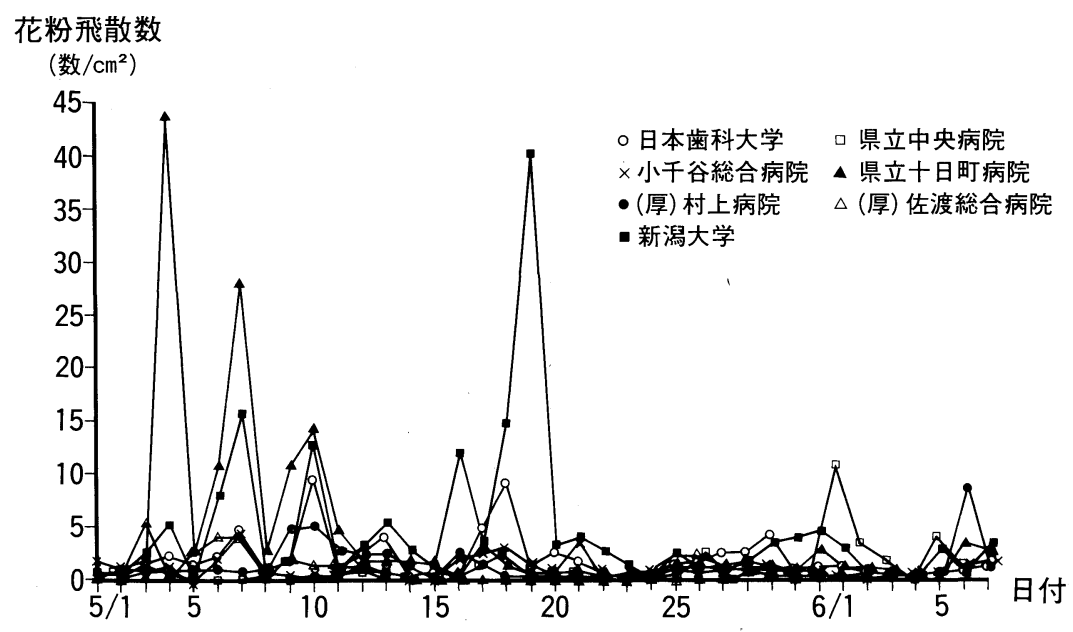

図2个ネ科花粉飛散状況 


\section{2 . 症 例}

回収症例は予防投与群 13 例, 発症後投与群 28 例であり，このうち解析対象となったのは予防 投与群11例，発症後投与群 25 例でその他の 5 例 は患者選択基準に該当しなかったり記載内容不 備のため除外症例となった．予防投与群は花粉 飛散の注湆 2 週間前から薬剂を投与したことに なり，全体で 6 週間の投与期間であった。発症 後投与群は汪とえどの例が 5 月上旬から中旬に かけて受診して和り, 予防投与群の症状のピー クおよび花粉飛散のピークと汪注一致していた。
この群では，全体で 4 週間の投与期間であった． これらの症例のアレルギー性の背景を表 3 亿示 したが，発症後投与群で女性が多かったこと， および予防投与群で軽症, 無症状症例が多かっ たことの注かは両群間で各項目とも差はみられ なかった

3 . 効 果

1 ) 症状別効果

a ）鼻症状に対する効果：予防投与群では「く しゃみ」,「鼻汁」, 「鼻閉」,「日常生活の支障度」 いずれも $90 \%$ 以上の抑制率 (中等度以上)であっ

表 3 患者背景

\begin{tabular}{|c|c|c|c|}
\hline \multicolumn{2}{|r|}{ 項 } & 予防投与群(\%) & 発症後投与群 (\%) \\
\hline 性別 & $\begin{array}{l}\text { 男 } \\
\text { 女 }\end{array}$ & $\begin{array}{ll}5 & (45.5) \\
6 & (54.5) \\
\end{array}$ & $\begin{array}{rr}5 & (20.0) \\
20 & (80.0) \\
\end{array}$ \\
\hline 年齢 & $\begin{array}{l}10 \sim 19 \\
20 \sim 29 \\
30 \sim 39 \\
40 \sim 49 \\
50 \sim 59 \\
60 \sim\end{array}$ & $\begin{array}{ll}0 & \left(\begin{array}{l}0 \\
1\end{array}\right) \\
1 & (9.1) \\
4 & (36.4) \\
1 & (9.1) \\
5 & (45.5) \\
0 & (0)\end{array}$ & $\begin{array}{ll}3 & (12.0) \\
1 & (4.0) \\
7 & (28.0) \\
4 & (16.0) \\
9 & (36.0) \\
1 & (4.0) \\
\end{array}$ \\
\hline 診 断 名 & $\begin{array}{l}\text { カモガヤ花粉症 } \\
\text { オオアワガエリ花粉症 } \\
\text { 合併例 }\end{array}$ & $\begin{array}{ll}1 & (9.1) \\
7 & (63.6) \\
3 & (27.3) \\
\end{array}$ & $\begin{array}{rr}9 & (36.0) \\
3 & (12.0) \\
13 & (52.0) \\
\end{array}$ \\
\hline 罹病期間 & $\begin{array}{l}3 \text { 年未満 } \\
3 \sim 10 \text { 年未満 } \\
\text { 10年以上 } \\
\text { 不 明 } \\
\text { 記載なし }\end{array}$ & $\begin{array}{ll}0 & (0) \\
9 & (81.8) \\
2 & (18.2) \\
0 & (0)\end{array}$ & $\begin{aligned} 8 & (32.0) \\
10 & (40.0) \\
4 & (16.0) \\
2 & (8.0) \\
1 & (4.0)\end{aligned}$ \\
\hline 重 症 度 & $\begin{array}{l}\text { 重 症 } \\
\text { 中等症 } \\
\text { 軽 症 } \\
\text { 無症状 }\end{array}$ & $\begin{array}{ll}8 & (72.7) \\
3 & (27.3) \\
\end{array}$ & $\begin{array}{rr}15 & (60.0) \\
8 & (32.0) \\
2 & (8.0)\end{array}$ \\
\hline 病 & $\begin{array}{l}\text { くしゃみ・鼻汁型 } \\
\text { 韻閉型 } \\
\text { くしゃみ・鼻閉型 } \\
\text { 韻汁・鼻閉型 }\end{array}$ & $11(100.0)$ & $\begin{aligned} 22 & (88.0) \\
1 & (4.0) \\
1 & (4.0) \\
1 & (4.0)\end{aligned}$ \\
\hline
\end{tabular}

表 4 鼻症状別予防効果

\begin{tabular}{|c|c|c|c|c|c|c|}
\hline 症 状 & 症例数 & $\begin{array}{l}\text { 著明な } \\
\text { 予防効果あり }\end{array}$ & $\begin{array}{l}\text { 中等度の } \\
\text { 予防効果あり }\end{array}$ & $\begin{array}{l}\text { 軽度の } \\
\text { 予防効果あり }\end{array}$ & 予防効果なし & $\begin{array}{l}\text { 抑制率 (\%) } \\
\text { (中等度以上) }\end{array}$ \\
\hline くしゃみ & 11 & 6 & 4 & 1 & 0 & 90.9 \\
\hline 鼻 汁 & 11 & 7 & 3 & 0 & 1 & 90.9 \\
\hline 鼻 閉 & 11 & 9 & 1 & 1 & 0 & 90.9 \\
\hline $\begin{array}{l}\text { 日常生活 } \\
\text { の支障度 }\end{array}$ & 11 & 8 & 2 & 1 & 0 & 90.9 \\
\hline
\end{tabular}


た(表 4 ). 一方発症後投与群では $20.8 \%$ から $60.9 \%$ 改善率 (中等度改善以上)であり(表 5 )，予防投与群の抑制率が非常に高かった。

b ）眼症状に対寸る効果：「眼のかゆみ」,「流 涙」,「充血」のいずれの症状に対しても予防投 与群は $100 \%$ の抑制率であったのに対し(表 6 ), 発症後投与群では $61.1 \%$ から $75.0 \%$ 改善率で あり (表 7 ), 予防投与群の方に高い効果がみら れた。

c）アレルギー日記による鼻症状の変化：ア レルギー日記の回収状況は記載が注㜔完なも のは予防投与群で 9 例, 発症後投与群で18例で あった。この鼻症状を経時的にみてみると，予
防投与群では「くしゃみ」,「鼻汁」，「鼻閉」と も花粉飛散期に入ると徐々に症状が増大してい ったが，それぞれの時期で統計学的有意差はな かった（図 3 )。こ机に対して，発症後投与群で は「くしゃみ」，「鼻汁」，「鼻閉」とも薬剤投与 後統計学的有意差をもって徐々に減少していた (図 4).

2 ）全般的予防効果拈よび治療効果

効果判定会で判定した予防投与群での全般的 予防率は $90.9 \%$ (中等度以上)であり（表 8 ), 発 症後投与群での全般改善率は $44.0 \%$ (改善以上) であった(表 9 ).

表 5 鼻症状別治療効果

\begin{tabular}{|c|c|c|c|c|c|c|c|c|}
\hline 症 状 & 症例数 & 著明改善 & 中等度改善 & 軽度改善 & 不 変 & 悪 化 & 症状なし & $\begin{array}{c}\text { 改善率 (\%) } \\
\text { (中等度改善以上) }\end{array}$ \\
\hline くしゃみ & 25 & 2 & 3 & 11 & 7 & 1 & 1 & 20.8 \\
\hline 鼻 汁 & 25 & 4 & 5 & 10 & 6 & 0 & 0 & 36.0 \\
\hline 鼻 閉 & 25 & 9 & 1 & 7 & 6 & 1 & 1 & 41.7 \\
\hline $\begin{array}{l}\text { 日常生活 } \\
\text { の支障度 }\end{array}$ & 25 & 13 & 1 & 4 & 5 & 0 & 2 & 60.9 \\
\hline
\end{tabular}

表 6 眼症状別予防効果

\begin{tabular}{|c|c|c|c|c|c|c|}
\hline 症 状 & 症例数 & $\begin{array}{l}\text { 著明な } \\
\text { 予防効果あり }\end{array}$ & $\begin{array}{l}\text { 中等度の } \\
\text { 予防効果あり }\end{array}$ & $\begin{array}{l}\text { 軽度の } \\
\text { 予防効果あり }\end{array}$ & 予防効果なし & $\begin{array}{c}\text { 抑制率 } \\
\text { (中等度以上) }\end{array}$ \\
\hline 眼のかゆみ & 11 & 11 & 0 & 0 & 0 & 100.0 \\
\hline 流 涙 & 11 & 11 & 0 & 0 & 0 & 100.0 \\
\hline 充 血 & 11 & 10 & 1 & 0 & 0 & 100.0 \\
\hline
\end{tabular}

表 7 眼症状別治療効果

\begin{tabular}{|c|c|c|c|c|c|c|c|c|}
\hline 症 状 & 症例数 & 著明改善 & 中等度改善 & 軽度改善 & 不 変 & 悪 化 & 症状なし & $\begin{array}{c}\text { 改善率 (\%) } \\
\text { (中等度改善以上 }\end{array}$ \\
\hline 眼のかゆみ & 25 & 11 & 0 & 2 & 5 & 0 & 7 & 61.1 \\
\hline 流 涙 & 25 & 9 & 0 & 1 & 2 & 0 & 13 & 75.0 \\
\hline 充 血 & 25 & 5 & 0 & 0 & 1 & 1 & 18 & 71.4 \\
\hline
\end{tabular}


3）患者印象

治験終了時の問診による患者印象としては予 防投与群では「良かった」以上が $54.5 \%$, 発症 後投与群では $12.0 \%$ であった(表10).
4 ）副作用, 臨床検査成績

副作用と考支られるものは 3 例 $(8.3 \%)$ にみ られた。この内訳は眠気が 2 例, 投与終了時の GOT, GPT のわずかな上昇が 1 例であった。 眠気はいずれの症例も投与開始後まもなくより

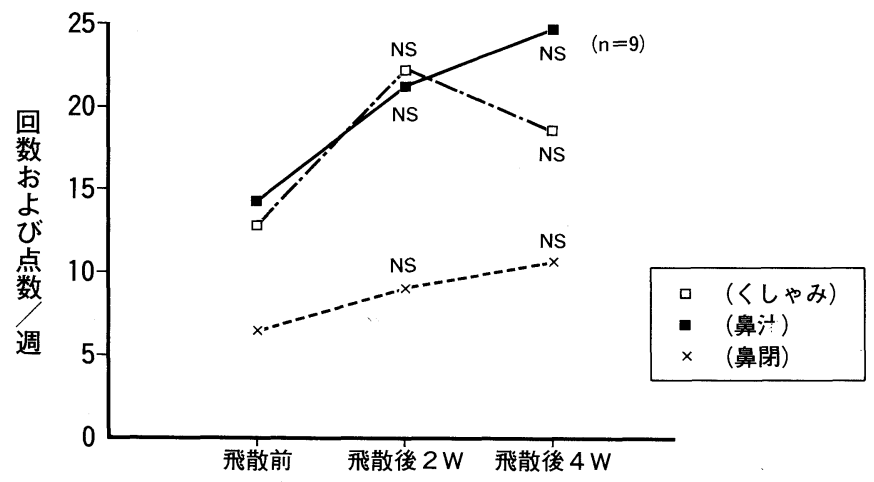

図 3 鼻症状の推移(予防投与群)

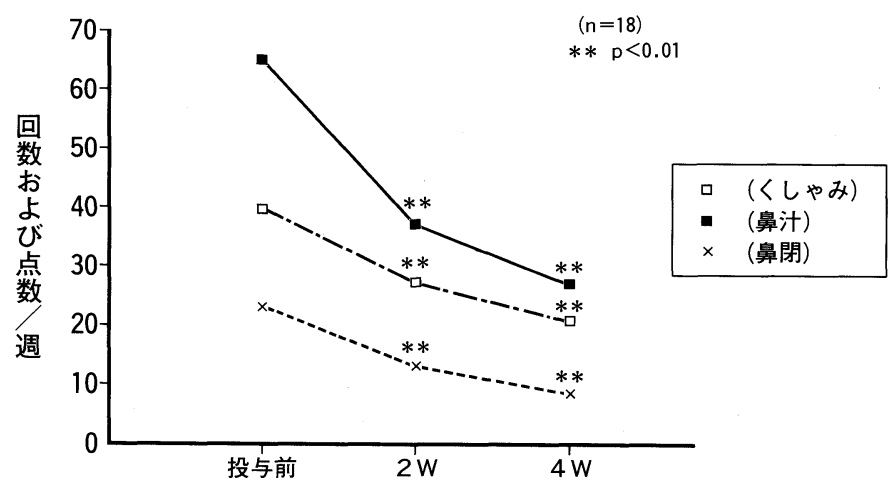

図 4 鼻症状の推移(発症後投与群)

表 8 全般的予防効果

\begin{tabular}{|c|c|c|c|c|c|}
\hline 症例数 & $\begin{array}{l}\text { 著明な } \\
\text { 予防効果あり }\end{array}$ & $\begin{array}{l}\text { 中等度の } \\
\text { 予防効果あり }\end{array}$ & $\begin{array}{l}\text { 軽度の } \\
\text { 予防効果あり }\end{array}$ & 予防効果なし & $\begin{array}{c}\text { 予防率(\%) } \\
\text { (中等度以上) }\end{array}$ \\
\hline 11 & 6 & 4 & 1 & 0 & 90.9 \\
\hline
\end{tabular}

表 9 全般的治療効果

\begin{tabular}{|c|c|c|c|c|c|c|}
\hline 症例数 & 著明改善 & 改 善 & やや改善 & 不 変 & 悪 化 & $\begin{array}{c}\text { 改善率 (\%) } \\
\text { (改善以上) }\end{array}$ \\
\hline 25 & 4 & 7 & 10 & 4 & 0 & 44.0 \\
\hline
\end{tabular}


出現し, 短期間の減量にて改善した. また臨床 検査値の異常は追跡調査で正常に回復している ことが確認された(表11).

5 ) 有用度

「有用」以上は予防投与群で $90.9 \%$, 発症後 投与群で $48.0 \%$ で予防投与群の方が有用率が高 かった(表12).

\section{考察}

最近花粉症に対して抗アレルギー剂が盛んに 使用されるようになってきたが，この薬剤を予 防的にあるいは治療として投与する場合にはい くつかの検討されなければならない問題がある。 まず第一は予防投与開始時期に関してであるが， いままで本薬剤の予防投与の治験はスギ花粉症 に対しての及行われて扣り，その開始時期は 1
〜 2 カ月前から行ったもの 8$)$, 拈よび $2 \sim 3$ 週 間前から行ったもの の910) が報告されている。 た他の薬剤によるスギ花粉症に対する予防投与 に抬いては $1 \sim 2$ 週間といら報告が多くみられ る1) 6). したがって本治験では例年のイネ科花 粉飛散開始時の 2 週間前, 寸なわち 4 月中旬か らの投与を予定し，注淁予定ど和り行うことが できた。その結果, 予防投与群では鼻执よび眼 諸症状に対する効果, 全般的予防効果, 有用度 がいずれもかなり高率であった。ささらに予防投 与群ではアレルギー日記による観察でも飛散 ピーク時の激しい症状の出現が抑制された。 こ のことからイネ科花粉症では 2 週間前からの本 薬剤予防投与が花粉症発症を抑制するために有 効な治療法と思われた。

表10 患者印象

\begin{tabular}{|c|c|c|c|c|c|c|c|c|}
\hline & 症例数 & $\begin{array}{l}\text { 大変 } \\
\text { 良かった }\end{array}$ & 良かった & $\begin{array}{l}\text { やや } \\
\text { 良かった }\end{array}$ & $\begin{array}{l}\text { 変わら } \\
\text { な }\end{array}$ & 悪かった & $\begin{array}{l}\text { 有効率 }(\%) \\
\text { (良かった上) }\end{array}$ & $\begin{array}{l}\text { わから } \\
\text { な }\end{array}$ \\
\hline 予防 投与 群 & 11 & 4 & 2 & 2 & 3 & 0 & 54.5 & \\
\hline 発症後投与群 & 25 & 0 & 3 & 2 & 13 & 4 & 12.0 & 3 \\
\hline
\end{tabular}

表11 副作用一覧表

\begin{tabular}{|c|c|c|c|c|c|c|}
\hline $\begin{array}{l}\text { 症例 No. } \\
\text { 性・年齢 }\end{array}$ & 症状 & 程度 & 発現日 & 処置 & 関連性 & 主治医コメント \\
\hline $\begin{array}{c}5 \\
\text { 女· } 55\end{array}$ & $\begin{array}{l}\text { GOT } \\
\text { GPT } \\
\text { 上昇 }\end{array}$ & 軽度 & 55日目 & $\begin{array}{l}\text { 投与 } \\
\text { 終了 }\end{array}$ & 否定できない & $\begin{array}{l}\text { 正常値をわずかに超える程度（GOT28・GPT } \\
\text { 32）なので, 正常の variation 内かも知れな } \\
\text { い。86日目に回復 }\end{array}$ \\
\hline $\begin{array}{c}13 \\
\text { 女· } 48\end{array}$ & 眠気 & 軽度 & 2 日目 & 減量 & 濃 い & $\begin{array}{l}\text { 眠気があったため, } 1 \text { 日 } 1 \text { 回夜のみ内服した } \\
\text { ところ軽快 }\end{array}$ \\
\hline $\begin{array}{c}26 \\
\text { 女· } 57\end{array}$ & 眠気 & 軽度 & 1 日目 & 減量 & 否定できない & $\begin{array}{l}\text { 血圧が高く内科医より精神安定剤（デパス }{ }^{\circledR}, \\
\left.\text { リーゼ }{ }^{\circledR}\right) \text { が処方されており, 併用により症状 } \\
\text { が出現したと考えられる。2 日目より軽快 }\end{array}$ \\
\hline
\end{tabular}

表12 有用度

\begin{tabular}{|c|c|c|c|c|c|c|c|}
\hline & 症例数 & $\begin{array}{c}\text { 極めて } \\
\text { 有 用 }\end{array}$ & 有 用 & やや有用 & $\begin{array}{l}\text { どちらとも } \\
\text { いえない }\end{array}$ & $\begin{array}{l}\text { 有用で } \\
\text { な }\end{array}$ & $\begin{array}{l}\text { 有用率(\%) } \\
\text { (有用以上) }\end{array}$ \\
\hline 予防 投与群 & 11 & 5 & 5 & 0 & 1 & 0 & 90.9 \\
\hline 発症後投与群 & 25 & 4 & 8 & 8 & 4 & 1 & 48.0 \\
\hline
\end{tabular}


次に発症後投与群での治療効果をみると，こ れは予防投与群と比較して多少有効性が低い上 らに思われた。両者の効果判定基準が異なるた めに単純には統計学的有意差が算出できないが， 実際の効果ではかなりの差がでていた。これは アゼラスチンが抗アレルギー作用に比べ抗ヒス タミン作用が多少弱い可能性も一因としてあげ られる.このことはわれわれがアゼラスチンで 行った通年性鼻アレルギー患者に対する治験で も明らかになっている。すなわちアゼラスチン 単独ではあまり効果がなかった症例には抗ヒス タミン剂と併用すると効果が増強することが判 明している11)。よって花粉症のように症状が強 いものでは花粉飛散ピーク時には抗ヒスタミン 剂の併用も考慮しなければならないものと思わ れる．ただし本薬剤の発症後投与群に対する治 療効果 (改善率 $44.0 \%$ ) は他の薬剂の発症後投与 時の治療効果4)5112) と比較して決して低いもの ではないしまたアレルギー日記の観察からも， 症状は経時的に有意差をもって減少している。

副作用は 3 例 (8.3\%)にみられた。これは本 薬剂の通年性扔よび季節性アレルギー症例に対 する従来の治験時の副作用 $0^{11) 13)} \sim 20.0 \%{ }^{14)}$ の 範囲内であった。 3 例の副作用症例中 2 例は薬 剂投与開始直後に発生した眠気であり，これは 軽度で, 薬剤の減量にて改善し, その後の投与 が可能であった。すなわち初期の眠気の副作用 は投与量や投与期間が増すにつれて軽減してい くものと思われた.

以上のことから今後はイネ科花粉症に対して はアゼラスチンの 2 週間前からの予防投与が症 状の発症を抑制する有効な治療法であると思わ れた。

\section{まとめ}

イネ科花粉症に対してアゼラスチンの予防投 与と発症後投与を行い, 以下の結論を得た.

1. 予防投与群では鼻拉よび眼症状に対する 抑制率，全般的予防効果，有用度のいずれも 90 \%以上であり, 有効率が非常に高かった.

2. 発症後投与群は従来の通年性鼻アレル
ギーに対する治療効果の報告に比べて有効率が 多少低かった.

3. 副作用の多くは眠気で, 投与開始直後に 出現することがあるが，一時的減量で消失し， 薬剤継続に支障はなかった。

以上よりイネ科花粉症に対してはスギ花粉症 と同様アゼラスチンの予防投与が発症を抑兄る 有効な方法と思われた.

\section{参考文献}

1）木村廣行, 矢島 洋, 羽田達正 : スギ花粉症に お流る予防的投薬の検討 -(I) DSCG，Tranilast の予防効果一. 耳鼻 32 : 416 424, 1986.

2）奥田 稔, 矢島 洋, 古内一郎, 他: スギ花粉 症に対するトラニラストの季節前投与による予 防効果一多施設間比較二重盲検法による検 討一. 耳展 30 補 $3: 219 \sim 243,1987$.

3）奥田 稔, 古内一郎, 佐々木好久, 他: スギ花 粉症に対するケトチフェン季節前投与の予防効 果. 耳展 29 補 $3: 277 \sim 293,1986$.

4) 辻田達郎, 井口郁雄, 西岡出雄, 他 : 花粉症に 対するセルテクト (Oxatomide) の予防ならびに 治療効果の検討. 診と薬 $26: 89 \sim 96,1989$.

5）奥田 稔, 斉藤洋三, 石井哲夫, 他 : スギ花粉 症に対するオキサトミドの予防・治療効果. 耳 展 32 補 $4: 295 \sim 323,1989$.

6）奥田 稔, 小川 浩, 斉藤洋三, 他: スギ花粉 症に対するアンレキサノクスの季節前・中投与 による予防扣よび治療效果についてープラセ ボとの二重盲検群間比較試験一.耳展 34 補 1 : 67〜89, 1991.

7）奥田 稔：鼻アレルギー診療の実際. 新臨床医 学文庫(改訂第 4 版). 183 188頁, 金原出版, 東京, 1979 .

8）吉見龍一郎，今里 滋，中田孝重：又ギ花粉症 の治療 一アゼラスチンの季節前投与一. 耳展 31 補 $1: 1 \sim 6,1988$.

9）奥田 稔, 佐々木好久, 石井哲夫, 他：スギ花 粉症に対するアゼラスチンの予防拈よび治療効 果の検討 一プラセボとの二重盲検群間比較試 験一. 耳展 32 補 1:37 54, 1989.

10）古屋英彦, 賀来光寛, 佐々間武司, 他 : アゼプ チン®のスギ花粉症に対する効果.耳鼻臨床 $84:$ 386 403, 1991. 
11）山岸益夫, 長谷川聡, 中野雄一, 他 : アゼラス チン(アゼプチン®) の鼻アレルギーに対する 臨床効果执よび抗ヒスタミン剤併用による増強 効果. 耳展 33 補 $1: 67 \sim 76,1990$.

12）山岸益夫, 長谷川聡, 中野雄一, 他：ヨモギ花 粉症に対するオキサトミド(セルテクト®) の 予防効果と治療効果. 耳展 33 補 $6: 717 \sim 726$, 1990.

13）前田 学, 西岡慶子, 内藤好宏, 他：鼻アレル ギーに対する塩酸アゼラスチンの効果. 耳鼻臨
床 $82: 1031 \sim 1038,1989$.

14）榎本和子, 荒ひろみ, 砂金英充, 他：鼻アレル ギーに対するE-0659の使用経験. 臨床と研究 $60: 3114 \sim 3122,1983$.

$\left(\begin{array}{l}\text { 原稿受付: 平成 } 3 \text { 年 } 4 \text { 月 } 26 \text { 日 } \\ \text { 原稿採択 : 平成 } 3 \text { 年 } 5 \text { 月 } 7 \text { 日 急載 } \\ \text { 別刷請求先 : 山岸益夫 } \\ \text { 干 } 951 \text { 新潟市旭町通一番町 } 754 \\ \text { 新潟大学医学部耳鼻咽喉科学教室 }\end{array}\right)$

